\title{
RESEARCH ON POSSIBILITY OF USING PLANT-DERIVED MATERIALS IN FRICTION ELEMENTS OF SLOW-RUNNING AGRICULTURAL MACHINERY BRAKING SYSTEMS
}

\author{
Andrzej Borawski, Eliza Borawska, Slawomir Obidzinski \\ Bialystok University of Technology, Poland \\ a.borawski@pb.edu.pl, eliza.borsztejn@wp.pl, s.obidzinski@pb.edu.pl
}

\begin{abstract}
Brakes are one of the most important components of every vehicle, including agricultural machines (tractors, harvesters, etc.). The nature of the brakes causes generation of abrasive wear products. Unfortunately, they get into the environment and cause its pollution. Nowadays, great emphasis is placed on environmental protection, which is why in this work an attempt was made to use plant waste materials as one of the components of friction material (as reinforcement) used for the production of friction linings. The fibrous nature of the stalks used gives great hope for a composite suitable for use in the braking systems of vehicles traveling at low speeds (like agricultural machines). Of many available plants, rye stalks were selected for the experiment. They were obtained as a local farm waste. The fibres were milled to the desired size and then mixed with the other ingredients. Five samples with different percentage composition were prepared. Then they were tested in laboratory. For this purpose, a pin-on-disc stand was used, which allows the determination of selected friction pair cooperation parameters. Using this test stand, the values of the friction force between the sample and the counter sample were determined. This value was used to calculate the coefficient of friction for each case. Then, measuring the weight loss (as a difference in the sample weight before and after the test), the abrasive wear rate was calculated for each sample. The obtained results show the differences between the prototype friction material and materials similar to commercial. The quantity of differences gives hope for the possibility of using waste materials of plant origin in the production of friction materials used in brake pads. Therefore, the composition presented in the paper contributes to environmental protection.
\end{abstract}

Keywords: mechanical engineering, plant wastes, friction, wear, brakes.

\section{Introduction}

The high civilizational development of today's society has some consequences. The biggest of these is irreversible destruction of the natural environment $[1 ; 2]$. Many researchers from various institutions are trying to prevent, or at least limit that destruction. One of the promising possibilities is the modernization of the automotive industry [3]. Advanced economy must be accompanied by highly developed transport, so it is important that all types of vehicles emit the lowest possible pollution, and that in their production (and production of their components) biodegradable or recyclable materials are used [4-6].

One of the most important components of each vehicle is the braking system. The brake system must be reliable and display unchanging action throughout its use time, as it guards the health and life of many people. When the speed decreases, two elements rub against each other, and as a result the kinetic energy of the movement changes into thermal energy. As this is accompanied by dry friction, numerous wear products are created. These products are components of friction materials and also new materials that arise as a result of high temperature and high pressure. Unfortunately, wear products end up in the environment causing pollution.

Properly matched friction pairs, a rotating disc or drum and standing still brake pad or shoes, have a great impact on these factors. In most cases, the disc (drum) is made of grey cast iron. The brake pads and shoes are far more complex components. Manufacturers utilize approximately 2000 different materials, which have different effects of the final product. An average brake pad or shoe consists of from 15 to 20 different substances [7]. Selecting the right composition for the friction material and predicting its impact on the final products, is a difficult task. It requires tremendous amounts of research and abundant experience. The decision must also take into account the intended use of the brake linings, and their operating conditions. The final properties of the friction material are also shaped by production technology, which is usually the best kept trade secret of every manufacturer. One of the many ingredients of the brake friction material is reinforcement [7-9]. The reinforcement is a fibrous material (one or more), which improves the binder's mechanical properties (increasing its strength). Different types of reinforcement materials have a significant impact on the durability and resistance of the brake pad, therefore, the selection cannot be random. In the past, asbestos was an excellent reinforcement fiber. However, due to its harmful properties [10], it was necessary to find a 
replacement (which today is no problem at all, since there is a whole range of materials, which can be used successfully to this end $[11 ; 12])$.

Today's industry generates a lot of waste, including biological waste, e.g. of plant origin. They can be used in various ways, e.g. as fuel $[13 ; 14]$. The cases of using banana peels $[15 ; 16]$, palm kernel shells [17; 18], cocoa beans [19-21] or periwinkle shells [22;23] as a component of friction material are also becoming more and more well known.

Having the above in mind, the aim of the study was to find out, if there is a possibility to produce a composite friction material with waste of plant origin as one of the components.

\section{Materials and methods}

The object of the study was samples of prototype friction material containing dried rye stalks, which are currently widely used in industry [24-26]. They were obtained as waste after the threshing process. The stalks were shredded into fragments about $3-5 \mathrm{~mm}$ long. A total of 5 samples with different percentage of rye were made: $0,5,10,15,20 \%$ of total material weight. Proportions were measured using a scale (Fig. 1). The exact composition of each sample is summarized in Tab. 1. The samples were made as cylindrical objects with a diameter of 1 " and a height of $10 \mathrm{~mm}$. Steel discs were used as the basis, which greatly facilitated the sample production process (Fig. 2).

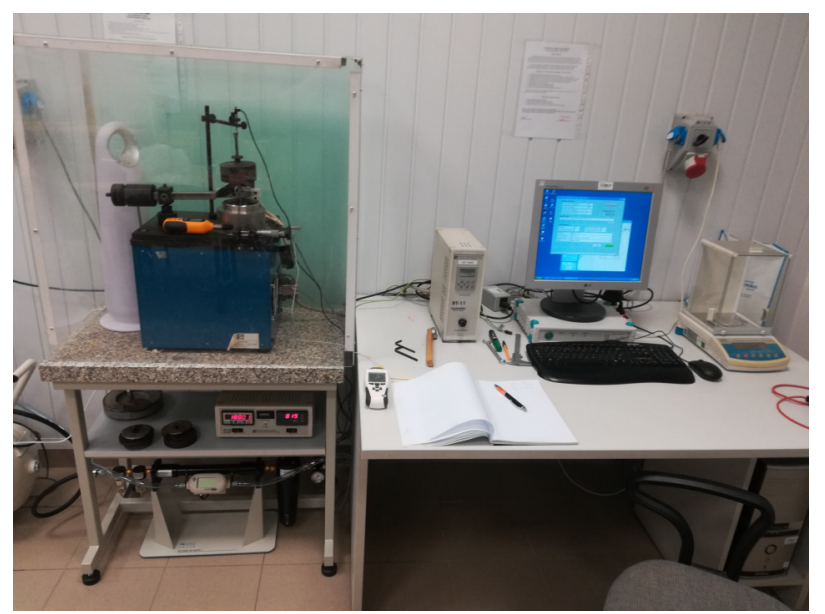

Fig. 1. Test stand

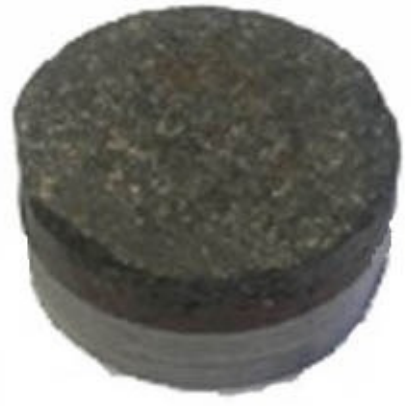

Fig. 2. One of the samples

Composition of prototype samples

Table 1

\begin{tabular}{|c|c|c|c|c|c|c|c|}
\hline $\begin{array}{c}\text { Sample } \\
\text { No. }\end{array}$ & $\begin{array}{c}\text { Rye } \\
\text { stalks }\end{array}$ & Fly ash & $\begin{array}{c}\text { Steel, Cu } \\
\text { and Al } \\
\text { fibers }\end{array}$ & $\begin{array}{c}\text { Abrasive: } \\
\mathbf{Z r S i O}_{\mathbf{4}}\end{array}$ & Graphite & $\begin{array}{c}\text { Resin } \\
\text { (matrix) }\end{array}$ & $\begin{array}{c}\text { Fillers: } \\
\text { BaSO }_{4}\end{array}$ \\
\hline 1 & $0 \%$ & $16 \%$ & $15 \%$ & $15 \%$ & $8 \%$ & $21 \%$ & $25 \%$ \\
\hline 2 & $5 \%$ & $13 \%$ & $15 \%$ & $15 \%$ & $8 \%$ & $21 \%$ & $23 \%$ \\
\hline 3 & $10 \%$ & $11 \%$ & $15 \%$ & $15 \%$ & $8 \%$ & $21 \%$ & $20 \%$ \\
\hline 4 & $15 \%$ & $8 \%$ & $15 \%$ & $15 \%$ & $8 \%$ & $21 \%$ & $18 \%$ \\
\hline 5 & $20 \%$ & $6 \%$ & $15 \%$ & $15 \%$ & $8 \%$ & $21 \%$ & $15 \%$ \\
\hline
\end{tabular}

The T-11 test stand (with pin-on-disc combination) was used in the research. It is located at the Faculty of Mechanical Engineering of the Bialystok University of Technology. Despite many types of tribotesters, this station is commonly used for testing friction materials [27-30]. In addition, a Radwag WAS 160/C/2 scale (accuracy: $\pm 0.1 \mathrm{mg}$ ), MT886 hygrometer (accuracy: $\pm 3 \%$ ), and Velleman DEM106 temperature sensor (accuracy: $\pm 0.1^{\circ}$ ) were used (Fig. 1).

Experimental studies have many advantages, the largest of which is an accurate representation of the actual process [31-33]. Thanks to this, very good quality results are obtained, which is not always possible in the case of simulation tests, in which a number of simplifications are often assumed [3435]. Laboratory tests, however, require proper planning, which is aimed, for example, at reducing the 
number of repetitions, therefore, reducing the duration of the test [36; 37]. In these tests, the input parameters of the experiment, i.e. speed, friction path, diameter of cooperation and load, were assumed for all tests constant and equal, respectively: speed $v=1 \mathrm{~m} \cdot \mathrm{s}^{-1}$, path $S=1000 \mathrm{~m}$, cooperation diameter $d=18 \mathrm{~mm}$, and load $Q=5 \mathrm{~kg}$. The tests were carried out at an air humidity of $35 \%$ and a temperature of $22{ }^{\circ} \mathrm{C}$. In addition, each sample was weighed before and after the test. This was to determine the amount of material loss. The counter-sample was a $6 \mathrm{~mm}$ diameter cylinder made of gray cast iron (Z1250).

\section{Results and discussion}

The direct results of the performed tests were the friction force values of the counter-sample against the sample. The original software of test stand automatically saved its value every $0.5 \mathrm{~s}$, which gave 2000 measuring points and allowed the determination of the friction force time profiles (Fig. 3). The course of graph makes it possible to distinguish the run-in period and the period of specific friction. In this case it took about $125 \mathrm{~s}$ to run-in.

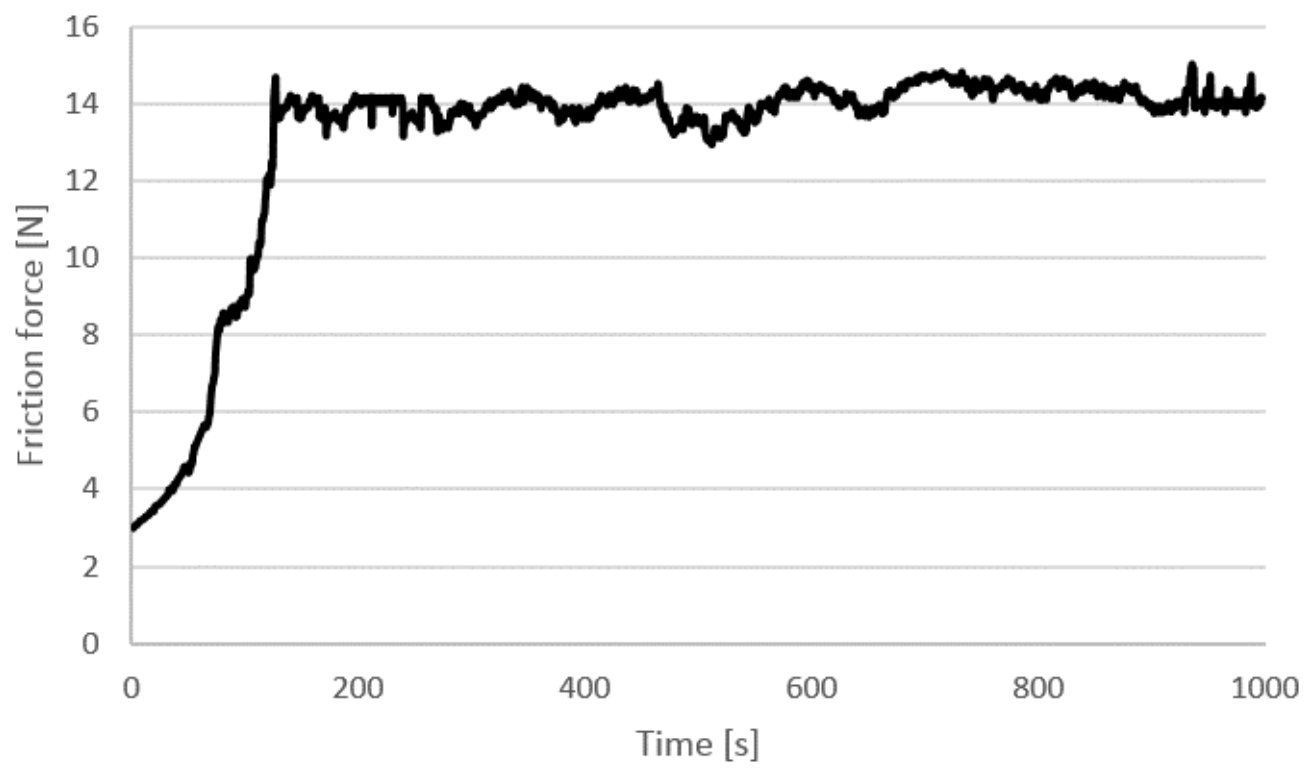

Fig. 3. One of the fiction force time profiles

After rejecting the running-in period, the average friction force was calculated for each sample. Then, using the Amonton-Coulomb law of friction [38], the value of the coefficient of friction can be calculated, which in this case is:

$$
\mu=\frac{F_{f}}{Q \cdot g}
$$

where $F_{f}$ - friction force, $\mathrm{N}$;

$Q$ - mass of the load, $\mathrm{kg}$;

$g$ - gravity constant, $\mathrm{m} \cdot \mathrm{s}^{-2}$.

After testing on the T-11 stand, each sample was washed, dried and then weighed. Next, the average weight loss relative to the pre-test state was calculated for each sample. Then, using the Archard equation, the abrasive wear rate was calculated:

$$
K_{c}=\frac{S \cdot Q \cdot g}{V}
$$

where $S$ - length of the friction path, m;

$V$ - loss of the material volume, $\mathrm{m}^{3}$.

Archimedes' law was used to determine the density of samples. A summary of the results obtained in research is shown in Tab. 2. 
Research results

\begin{tabular}{|c|c|c|c|c|c|}
\hline $\begin{array}{c}\text { Sample } \\
\text { No. }\end{array}$ & $\begin{array}{c}\text { Density, } \\
\mathbf{k g} \cdot \mathbf{m}^{-3}\end{array}$ & $\begin{array}{c}\text { Average } \\
\text { friction force, } \mathbf{N}\end{array}$ & $\begin{array}{c}\text { Coefficient of } \\
\text { friction }\end{array}$ & $\begin{array}{c}\text { Material loss, } \\
\mathbf{g}\end{array}$ & $\begin{array}{c}\mathbf{K}_{\mathbf{c}}, \\
\mathbf{1 0}^{\mathbf{- 1 3}} \mathbf{m} \cdot \mathbf{N} \cdot \mathbf{~ m}^{-3}\end{array}$ \\
\hline 1 & 3241 & $19.84 \pm 0.21$ & $0.404 \pm 0.004$ & $0.0032 \pm 0.1 \mathrm{mg}$ & $4.972 \pm 0.155$ \\
\hline 2 & 3027 & $18.43 \pm 0.14$ & $0.375 \pm 0.002$ & $0.0040 \pm 0.1 \mathrm{mg}$ & $3.714 \pm 0.093$ \\
\hline 3 & 2870 & $17.21 \pm 0.18$ & $0.350 \pm 0.003$ & $0.0043 \pm 0.1 \mathrm{mg}$ & $3.275 \pm 0.076$ \\
\hline 4 & 2735 & $16.55 \pm 0.12$ & $0.337 \pm 0.002$ & $0.0046 \pm 0.1 \mathrm{mg}$ & $2.917 \pm 0.063$ \\
\hline 5 & 2512 & $15.02 \pm 0.23$ & $0.306 \pm 0.005$ & $0.0048 \pm 0.1 \mathrm{mg}$ & $2.568 \pm 0.053$ \\
\hline
\end{tabular}

The obtained results show how the physical properties of the friction material change depending on its composition. The rye used for the production of samples is light and has low mechanical strength compared to other ingredients. This explains why as the percentage of this component increased, the density of the final product decreased. High percentage content caused a drop of about $26 \%$ in the density value (this will have a positive effect on the total weight of the vehicle). On the other hand, low mechanical strength caused a decrease in the coefficient of friction and the abrasive wear rate. COF drops about $25 \%$, and $K_{c}$ about $49 \%$. Analyzing the magnitude of these changes, it can be safely stated that the obtained values do not differ significantly from each other, or from the results obtained by other researchers while studding commercial friction materials [39-41].

The results showed that while the decrease in the coefficient of friction was not significant, the change in the abrasive wear rate was large. However, bearing in mind that the proposed material is to be intended for slow-moving vehicles, the $K_{c}$ value is not that important. In the near future more extensive research is planned (including high temperature cooperation), but it can already be said that in our opinion the use of plant-derived waste for the production of friction materials, especially working at low and moderate temperatures, is possible, as shown by the results of this work.

\section{Conclusions}

For the purpose of this work, five samples of prototype friction material containing plant-derived waste as one of the components were made. After performing a series of tests, it was established that:

1. The tests allowed to determine the values of the friction force in cooperation with gray cast iron. This data were used to calculate the coefficient of friction for each sample. It turned out that its lowest value, $0.306 \pm 0.005$, was for samples with $20 \%$ rye stalks content. The highest $(0.404 \pm 0.004)$ was recorded for samples without rye stalks. Difference in both COF's is about $25 \%$.

2. The experiment also allowed to measure the scale of material loss. These values allowed to determine the abrasive wear rate. Samples with the highest rye stalk content are characterized by the fastest wear. The $K_{c}$ value was $2.568 \pm 0.053$ for them. The highest abrasive ware rate was noted for samples without rye stalks. The value was $4.972 \pm 0.155$.

3. The obtained results show that rye stalks can be used as a component of friction material, especially when working conditions do not require resistance to very high temperatures.

\section{Funding}

This publication was financed through the program of the Ministry of Science and Higher Education of Poland named "Regional Initiative of Excellence" in 2019-2022 project number 011/RID/2018/19.

\section{Acknowledgments}

This research was co-founded through the subsidy of the Ministry of Science and Higher Education for the discipline of Mechanical Engineering at the Faculty of Mechanical Engineering, Bialystok University of Technology. 


\section{References}

[1] Tyagi S., Garg N., Paudel R. Environmental Degradation: Causes and Consequences. European Researcher, vol. 81(8-2), 2014, pp. 1491-1502.

[2] Remoundou K., Koundouri P. Environmental Effects on Public Health: An Economic Perspective. Int J Environ Res Public Health, vol. 6(8), 2009, pp. 2160-2178.

[3] Alsaadi N.A., Franchetti M. An Integrated Approach to Vehicle Recycling Facilities. International Journal of Environmental Science and Development, vol. 7(11), 2016, pp. 856-860.

[4] Simic V. End-of-life vehicle recycling-A review of the state-of-the-art. Tehnicki Vjesnik, vol. 20(2), 2013, pp. 371-380.

[5] Mieczkowski G., Borawski A., Szpica D. Static electromechanical characteristic of a three-layer circular piezoelectric transducer. Sensors, vol. 20, 2020, 222, pp. 1-14.

[6] Szpica D. The influence of selected adjustment parameters on the operation of LPG vapor phase pulse injectors, Journal of Natural Gas Science and Engineering, vol. 34, 2016, pp. 1127-1136.

[7] Borawski A., Borawska E., Obidziński S., Tarasiuk W. Effect of the chemical composition of the friction material used in brakes on its physicochemical properties. Laboratory tests. Przemysl Chemiczny, vol. 99(5), 2020, pp. 1000-1004.

[8] Xiao X., Yin Y., Bao J. Review on the friction and wear of brake materials. Advances in Mechanical Engineering, vol. 8(5), 2016, pp. 1-10.

[9] Gujrathi T.V., Damale A.V. A review on friction materials of automobile disc brake pad. International Journal Of Engineering, Education And Technology, vol. 3(2), 2015, pp. 1-4.

[10]Borawski A. Simulation Study of the Process of Friction in the Working Elements of a Car Braking System at Different Degrees of Wear. Acta Mechanica et Automatica, vol. 12(3), 2018, pp. 221-226.

[11]Lemen, R.A. Asbestos in Brakes: Exposure and Risk of Disease. American Journal of Industrial Medicine, vol. 45(3), 2004, pp. 229-237.

[12] Ikpambese K.K., Gundu D.T., Tuleun L.T. Evaluation of palm kernel fibers (PKFs) for production of asbestos-free automotive brake pads. Journal of King Saud University Engineering Sciences, vol. 28, 2016, pp. 110-118.

[13] Ganguly A., George R. Asbestos free friction composition for brake linings. Bull. Mater. Sci., vol. 31(1), 2008, pp. 19-22.

[14] Obidziński S., Dołżyńska M., Kowczyk-Sadowy M. Densification and Fuel Properties of Onion Husks. Energies, vol. 12(24), 2019, pp. 1-18.

[15] Dołżyńska M., Obidziński S., Kowczyk-Sadowy M. Densification and Combustion of Cherry Stones. Energies, vol. 12(16), 2019, pp. 1-15.

[16] Idris U.D., Aigbodion V.S., Abubakar I.J. Eco-friendly asbestos free brake-pad: Using banana peels. Journal of King Saud University - Engineering Sciences, vol. 27(2), 2015, pp. 185-192.

[17] Masrat B., Sheikh S.S., Owais B. Friction and wear behavior of disc brake pad material using banana peel powder. International Journal of Research in Engineering and Technology, vol. 4(2), 2015, pp. 650-659.

[18] Okoroigwe E.C., Saffron C.M., Kamdem P.D. Characterization of palm kernel shell for materials reinforcement and water treatment. Journal of Chemical Engineering and Materials Science, vol. 5(1), 2014, pp. 1-6.

[19] Ibhadode A.O.A., Dagwa I.M. Development of asbestos-free friction lining material from palm kernel shell. Journal of the Brazilian Society of Mechanical Sciences and Engineering, vol. 30(2), 2008, pp. 166-173.

[20] Olupona J.A., Abodunwa J.A., Fayoyin F.K. Response of laying hens to graded levels of cocoa bean shells. Proceedings of 28th Ann. Conf., Nig. Soc. Anim. Prod., vol. 28, 2003, pp. 247-249.

[21] Dan-Asabe B., Madakson P.B., Manji, J. Material Selection and Production of a Cold-Worked Composite Brake Pad. World J of Engineering and Pure and Applied Sci., vol. 2(3), 2012, pp. $92-$ 97.

[22] Olabisi A.I., Adam A.N., Okechukwu O.M. Development and Assessment of Composite Brake Pad Using Pulverized Cocoa Beans Shells Filler. International Journal of Materials Science and Applications, vol. 5(2), 2016, pp. 66-78.

[23] Aku S.Y., Yawas D.S., Madakson P.B. Characterization of periwinkle shell as asbestos-free brake pad materials. Pacific Journal of Science and Technology, vol. 13(2), 2012, pp. 57-63. 
[24]Elakhame Z.U., Olotu O.O., Abiodun Y.O. Production of asbestos free brake pad using periwinkle shell as filler material. International Journal of Scientific \& Engineering Research, vol. 8(6), 2017, pp. 1728-1735.

[25] Ravindran R., Hassan S.S., Williams G.A., Jaiswal A.K. A Review on Bioconversion of AgroIndustrial Wastes to Industrially Important Enzymes. Bioengineering (Basel), vol. 5(4), 2018, 93.

[26] Özdamara E.G., Ateş M. Rethinking sustainability: A research on starch based bioplastic. Journal of Sustainable Construction Materials and Technologies, vol. 3(3), 2018, pp. 249-260.

[27] Guler C., Sahim H.I., Yeniay S. The potential for using corn stalks as a raw material for production particleboard with industrial wood chips. Wood research, vol. 61(2), 2016, pp. 299306.

[28] Borawski A. Common methods in analysing the tribological properties of brake pads and discs - a review. Acta Mechanica et Automatica, vol. 13(3), 2019, pp. 189-199.

[29] Borawski A. Suggested Research Method for Testing Selected Tribological Properties of Friction Components in Vehicle Braking Systems. Acta Mechanica et Automatica, vol. 10(3), 2016, pp. 223-226.

[30] Abdullah O. I., Schlattmann J. Temperature analysis of a pin-on-disc tribology test using experimental and numerical approaches. Friction, vol. 4(2), 2016, pp. 135-143.

[31] Mangesh S.P., Kolekar K.B. Review of Friction Material Effect on Performance of Disc Brake. International Journal for Research in Applied Science \& Engineering Technology, vol. 6(4), 2018, pp. 5096-5104.

[32] Szpica D. Investigating fuel dosage non-repeatability of low-pressure gas-phase injectors. Flow Measurement and Instrumentation, vol. 59, 2018, pp. 47-156.

[33] Szpica D. New Leiderman-Khlystov Coefficients for Estimating Engine Full Load Characteristics and Performance. Chinese Journal of Mechanical Engineering, vol. 32, 2019, pp. 1-14.

[34] Mieczkowski G., Molski K., Seweryn A. Finite-element modeling of stresses and displacements near the tips of pointed inclusions. Materials Science, vol. 43(2), 2007, pp.183-194.

[35] Mieczkowski G. Description of stress fields and displacements at the tip of a rigid, flat inclusion located at interface using modified stress intensity factors. Mechanika, vol. 21(2), 2015, pp.91-98.

[36] Mieczkowski G. Stress fields and fracture prediction for adhesively bonded bi-material structure with sharp notch located on the interface. Mechanics of Composite Materials, vol. 53(3), 2017, pp. 305-320.

[37]Lootsma F.A., Mensch T.C.A., Vos F.A. Multi-criteria analysis and budget reallocation in longterm research planning. European Journal of Operational Research, vol. 47(3), 1990, pp. 293-305.

[38] Healey P., Rothman H., Hoch P.K. An experiment in science mapping for research planning. Research Policy, vol. 15(5), 1986, pp. 233-251.

[39] Kulikowski K., Szpica D. Determination of directional stiffnesses of vehicels' tires under a static load operation, Maintenance and Reliability, Vol. 16(1), 2014, pp. 66-72.

[40] Xiao X., Yin Y., Bao J., Lu L., Feng, X. Review on the friction and wear of brake materials. Advances in Mechanical Engineering, vol. 8(5), 2016.

[41]Zhu Z.C., Xu L., Chen G.A. Effect of different whiskers on the physical and tribological properties of non-metallic friction materials. Mater Design, vol. 32, 2011, pp. 54-61.

[42] Ostermeyer G.P., Müller M. Dynamic interaction of friction and surface topography in brake systems. Tribol Int, vol. 39, 2006, pp. 370-380. 